\section{Earth science in a fabulous place}

\author{
Peter J. Smith
}

Atlantis in the Light of Modern

Research.

By Zdenĕk Kukal.

Elsevier: 1984. Pp.224. \$57.75, Dfl. 150.

How the childhood memories come flooding back! The idea of Atlantis was introduced early into my genteel upbringing, presumably as a spur to the imagination much as a spot of breakfast is supposed to set the digestive processes rolling. Plato's lost world beat its competitor, Little Noddy, hands down, losing its status as prime imaginative wonder of the world only under the impact of the higher Blytonian Island of Adventure and, later, the more robust yarns of Percy $F$. Westerman and Arthur Conan Doyle. Besides, in the black-and-white world of the teens, fiction was fiction and fact was fact, but fiction masquerading as fact (as, by then, we all knew Atlantis to be) was strictly for the gullible. When we became adults we put away childish things, did we not?

But no, actually, some of us didn't. N.F. Zhirov of the Soviet Union, reputedly the world's most devoted "atlantologist", is even now engaged in a review of all of the estimated 3,600 works on Atlantis published to date. A Dr E. Sykes is said to edit Atlantean Research, a periodical containing such gems as "Atlantis, land of giants" and "Atlantian script". Pierre Benoit wrote the most famous of all novels about the place. And Zdenék Kukal, a member of the Geological Survey of Czechoslovakia and author of more than 200 legitimate papers and books on matters geological, now presents the results of 20 years' study of the scientific aspects of Atlantis.

What these four representatives of a much larger motley demonstrate, of course, is that Atlantis has a number of distinct faces. There is Atlantis as jumpingoff point for harmless fantasy, which sees Plato as an early science-fiction writer. To the extent that fantasy is therapeutic, here surely lies Atlantis's most abiding contribution to the welfare of the human race, although Kukal ignores all that because it is not science. Then there is Atlantis as advanced civilization. But is it likely that there was really, as Plato claimed, a ten-million-strong community that could write, work metals and breed domestic animals many millennia before the time for which there is evidence of such things elsewhere? Kukal thinks not.

That leaves Atlantis as a physical, geographical and geological entity, albeit one that, according to Plato, suffered "violent earthquakes and floods, and in a single day and night of misfortune ... disappeared in the depth of the sea" about 11,500 years ago. Not that Plato's sea should be taken too literally, it seems, for of the 40-odd possible locations of Atlantis given in the literature (ranging from the United States to the Black Sea and from Iceland to Zimbabwe) almost half are on land. As far as the ocean floor is concerned, however, Kukal has to admit that echo sounding, deep-sea drilling, dredge and grab sampling, underwater photography and bathymetric descents have revealed not one whiff of Plato's place.

From this discouraging beginning Kukal goes on to assess in some detail whether we could just have missed the sunken state (possibly), whether city walls and metal artefacts could have survived 11,500 years of submergence anyway (highly unlikely), whether Atlantis could have been any of the fictitious islands shown on early maps (no), whether it could have been any of today's real islands (geologically impossible) and whether there are any areas of subsidence in the Atlantic or Mediterranean which might qualify (not really). He then considers whether the supposed Atlantis could have been destroyed by earthquake or tsunami (theoretically possible), storm flood (probably not), volcanic eruption (yes), slow tectonic movement (no), cosmic impact (no evidence) or rising sea level (yes, but not "in a single day and night").

There is something faintly ludicrous about all this; it is a bit like mounting a scientific search for the invisible man simply because H.G. Wells happened to write about one. On the other hand, in describing the search for Atlantis, Kukal does manage to impart a lot of earth science - the geology of islands and oceans, the nature of glaciation, the role of sea-level changes, the processes of weathering and much else besides. The means may not justify the ends, but they make a fascinating story all the same.

I began the book with an inclination to mock, but ended up with a grudging respect for Kukal. He has produced a fine and objective refutation of a "theory" that may be inherently ridiculous but is nevertheless important because it has duped thousands of people over the centuries. Atlantis was a deliberate fiction and a particularly successful one at that, for it still attracts attention after 2,500 years. The advanced civilization of Atlantis was Plato's Utopia; its physical and political structure was the best Plato could envisage; and its destruction was by processes known to him. There can be no other conclusion, although one almost wishes that after 20 years of work Kukal could have proved otherwise. Of course, the only people to accept his verdict will be those who believed it in the first place. Those who don't never will. All will continue much as if Kukal had never been.

Peter J. Smith is Reader in Earth Sciences at the Open University.

\section{Swimming through the cell}

\section{Tim Hunt}

A Guided Tour of the Living Cell, Vols 1 and 2.

By Christian de Duve.

W.H. Freeman:1985. Pp.423. \$55.95, $£ 39.90$ per set.

HERE is the latest biological work from W.H. Freeman in the Scientific American Library. It spans two volumes, but is a seamless whole and the two jackets are identical except for the words "One" and "Two". Like its predecessors in the series, A Guided Tour of the Living Cell is beautifully produced and written, and its author uniquely qualified to show us around. Christian de Duve is one of the great pioneers of cell biology; together with Albert Claude and George Palade, he was justly awarded the Nobel Prize in medicine in 1974 for his "discoveries concerning the structural and functional organization of the cell".

You may remember a film called The Incredible Voyage in which heroic brain surgeons operated on the patient by shrinking themselves down to a microscopic size and making their way to the site of the damage in a tiny submarine which was injected into a vein. The operation successfully completed, they escaped by means of the tear duct after many a frightening adventure, the worst an ugly encounter with a macrophage. In his books de Duve shrinks the reader even further, to the point where the very organelles of the cell are as huge caverns to the observer. What is more, we are protected only by a diving suit (a magic suit, it's true, made of the material that coats the leprosy bacillus) as we swim around the cell with the Master as our guide. The idea sounds perilously twee, and when the introduction reveals that these are the books of a series of childrens' Christmas lectures, the heart sinks even further. However, my initial suspicion wore off within a few pages and the idea works brilliantly well - they must have been fabulous lectures!

Not surprisingly, de Duve is at his best describing the workings of the membrane systems of the cell, and particularly in describing lysosomes. As he says "understanding, not description, is the true purpose of scientific exploration", and in this chapter understanding comes as if by enchantment. We are lucky in other ways besides. de Duve's language is plain, his images concrete and familiar, and the text is strewn with wise words. Several times I found myself warming, seeing things said that do not often appear in books of any kind, let alone relatively elementary texts. Other agreeable features of the general style are de Duve's readiness to admit ignorance and to point out 
puzzles, and his unfailing grace in explaining the (usually classical) origins of terms.

However, the Incredible Voyage ap. proach has its limitations, most evident in the biochemical parts of the books. Very few people really enjoy biochemistry, probably because of its rather abstract nature. It's a subject that's fun to $d o$, but not so much fun to read about. de Duve adopts two "outlandish terms" (sic) the "Janus Intermediate" and the "Oxphos Unit". The Janus Intermediate "arises from a nucleophilic attack by an oxygen containing building block $\left(\mathrm{X}-\mathrm{OH}\right.$ or $\left.\mathrm{X}-\mathrm{O}^{-}\right)$on exploring at greater length, precisely because it seems to cause such trouble. de Duve includes some appendices dealing with biochemistry and bioenergetics which would have been helpful in the body of the text, but they are at the end of the second volume so consulting them is not encouraged. Probably you either have to grasp the nettle and give the full treatment, or leave it out altogether.

In the nucleus we are for the most part in conceptual country which de Duve understands very well, but doesn't know like he knows his organelles. de Duve is not alone in speaking of "the nucleus" as stan-

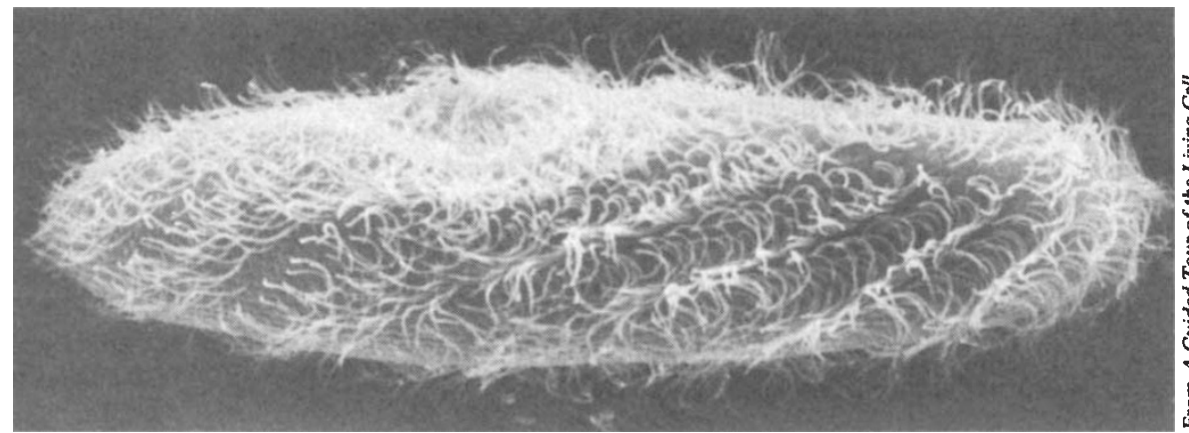

Stopped in time - rows of cilia on the surface of Paramecium tetraurelia arrested in the middle of their synchronous beat.

ATP or some related energy-rich molecule, which we will designate provisionally as $\mathrm{A}-\mathrm{B}$, in order to avoid going into complex chemistry"; later we learn that "Janus...is Mercury and Aquarius all in one"'. You see? The excellent colour graphics make it more palatable, but whereas other parts of the book repeatedly opened my eyes, I found the biochemistry and bioenergetics not only unilluminating but even baffling in places. I never really did get the Oxphos unit.

In his introduction, de Duve is apologetic about his approach to biochemistry, as if he knew he was taking a bit of a risk and hadn't quite got it the way he would have liked. It would be interesting to know how a non-biochemical reader would fare. It is very difficult to know how to deal with biochemistry in a modern account of the cell. Whether you are a strict cell biologist or a full-blooded clone-andsequence molecular man, enzymes and the reactions they catalyse keep on creeping into consciousness both as tools (don't forget to add the ATP to your ligations) and as the very objects of study; what does the recently discovered "homeoprotein" actually $d o$ ? Yet we shy from the gory biochemical details. Why should this be so? Is it because of a lingering distaste for the blood and guts origin of the subject? Or because our algebra stopped short of the MichaelisMenten equation, which we were led to think lay at the heart of the subject? Or because the chemical formulae were too big to remember, and the pathways too complex to comprehend except by rote the night before the exam? Or because explanations too often stopped before they really made sense? This is a topic that needs ding for almost all of molecular biology; this is common parlance among cell biologists. Yet molecular biology as I understand it has very little to do with the nucleus as such. It stands for a much more highly conceptualized scheme of things that transcends (for the time being) its cellular location. Actually, we don't even understand clearly why there is such a thing as a nucleus; bacteria get along without it and Saccharomyces cerevisiae commits mitosis without ever losing its nuclear membrane. Curiously, this kind of issue is not considered here. There is discussion of what the nuclear membrane lets in and out, of nuclear pores and how little we understand of how they work, of how the membrane vesiculates prior to mitosis (we have to wait for this to happen to get out!), but not of why it's there in the first place. (Alberts et al. in Molecular Biology of the Cell suggest that it's to keep protein synthesis out, thus allowing splicing to occur.) I was disappointed by de Duve's silence on the matter, for elsewhere he almost always has something interesting to say.

These two volumes are an extravagant buy for the individual, but they must go into my college library and I would advise intending biologists who have not done the subject at school to try and get hold of them before they go up to university. For, despite their deficiencies, the books are a splendid introduction to cell biology, and the first hundred pages could and probably should be read with profit and enjoyment by every biologist.

Tim Hunt is a Lecturer in the Department of Biochemistry at the University of Cambridge.
Nature magnified

Peter Evennett

Single Lens: The Story of the Simple Microscope.

By Brian J. Ford.

Heinemann/Harper \& Row: 1985.

Pp. 182. £10.95, \$14.95.

THE simple microscope, one whose optical system consists of a single lens, operating in the manner of a magnifying glass, has a distinguished place in history and quite remarkable capabilities, little known to the general scientist. The origins of its use are obscure, but by far the best known early work is that of Antony van Leeuwenhoek of Delft, communicated in the form of a series of letters to the Royal Society from 1673 until shortly before his death in 1723. One third of Brian Ford's book is devoted to Leeuwenhoek, his microscopes and specimens.

Using single-lens microscopes, Leeuwenhoek was the first to observe Protozoa, bacteria and spermatozoa: truly microscopic objects. In contrast Robert Hooke, Leeuwenhoek's contemporary working in London who published Micrographia in 1665, used a compound micro. scope (consisting of two lenses, objective and eyepiece). Both men's observations were excellent within their own limits, but while Hooke's work - on relatively large objects such as the flea or the sting of the nettle, for example - extended existing knowledge only slightly (though illustrating it most beautifully), Leeuwenhoek broke entirely new ground. The reason for this was principally his choice of microscope: lens design was then in its infancy and, to put it crudely, one poor lens gave better results than two poor lenses.

In addition to his letters, Leeuwenhoek also sent specimens, in small paper packets pasted to the letters; many of these survive in the archives of the Royal Society. In researching this book, Ford took some of the specimens to Utrecht and photographed them with an original microscope, demonstrating to those of us unlikely ever to lay hands on one the nature and quality of the image of a Leeuwenhoek microscope. A study of the surviving instruments shows that they were capable of resolving features as small as one micrometre, with a magnification of several hundred times - a performance as good as that of many school microscopes of today; indeed, for 300 years single-lens microscopes have been

\section{New in paperback}

- The ninth edition of Henderson's Dictionary of Biological Terms, revised by Sandra Holmes. Publisher is Longman, price $£ 4.50$.

- The Ecology of Animal Movement, edited by Ian R. Swingland and Paul J. Greenwood. Publisher is Oxford University Press, price $£ 12.50$. 